Ann. Biol. anim. Bioch. Biophys., 1978, 18 (4), 813-818.

\title{
Testicular feed back on the hypothalamo-pituitary axis in rainbow trout (Salmo gairdneri R.)
}

\author{
par R. BILLARD \\ with the technical assistance of Pierrette REINAUD \\ Laboratoire de Physiologie des Poissons, I. N. R. A., \\ 78350 jouy en josas, France.
}

Summary. A testicular feed back on the hypothalamo-pituitary system was studied in male rainbow trout (Salmo gairdneri) after bilateral castration and steroid or testicular supplementation. Experiments were carried out at various periods of the spermatogenetic cycle ; in March-April (resting stage), June (initiation of spermatogenesis), October (end of spermatogenesis and before spermiation), and December (running stage).

In March and April, plasma t-GTH is low in intact males $(<2 \mathrm{ng} / \mathrm{ml})$ and castration induced a threefold rise of GTH. Testosterone (T) given by a silastic capsule inserted in the body cavity of the castrate did not change plasma t-GTH in comparison with the intact control. When $T$ is given in the same manner in intact males GTH is significantly increased. In June, a significant t-GTH rise was observed after castration $(P<0.05)$, this rise was prevented by injection of $T$ and estradiol $\left(E_{2}\right)$. When $E_{2}$ and $T$ were given to intact males plasma t-GTH was significantly decreased. In October plasma t-GTH was high $(13 \mathrm{ng} / \mathrm{ml})$ and was not modified by castration ; injected $T$ or $E_{2}$ had no effects on plasma t-GTH either in intacts or castrates. In December, a sevenfold increase of t-GTH is observed after castration. This was partly suppressed by intraperitoneal injection of $T$ and $E_{2}$ and declined after stereotaxic implantation of 11-ketotestosterone into the pituitary. It was not significantly suppressed by intraperitoneal injection of testicular extracts. It is suggested that at this period steroids are the main gonadal factors involved in the feed back at the hypothalamo-pituitary system level.

\section{Introduction.}

In male rainbow trout in France spermatogenesis is initiated early in summer and spermiation occurs in November. More precisely, in the population we are using in the laboratory, spermatogenesis commences in May-June with a slow phase of type A spermatogonia division followed in June-July by a rapid phase of multiplicafion of type B spermatogonia. Meiosis and spermiogenesis occur in August-September. Spermatogenesis is completed in October at which time the testes are then full of spermatozoa, and also contain spermatogonia (stem-cells) which remain in a resting stage until May when the next spermatogenetic cycle is initiated. Spermiation starts in November and continues until February. However, males in a running stage may be found late in March and even in April, but spermatozoa are of a poor quality 
(low rate of motility) at this time and therefore February is considered as the end period of functional spermiation.

Previous experiments have shown that plasma GTH response to bilateral castration varies according to the stage of spermatogenesis (Billard et al., 1977). In the present work, bilateral castration and steroid supplementation were performed at various stages of this reproductive cycle. In addition, in December (running stage) when castration-induced rise of GTH is maximum, castrates received testicular extracts or 11-ketotestosterone (11-KT) which is the main testicular androgen (Idler et al., 1971).

\section{Material and methods}

Experiments were carried out in 1976 and 1977. Animal care and castration procedures are described in Billard et al. (1977).
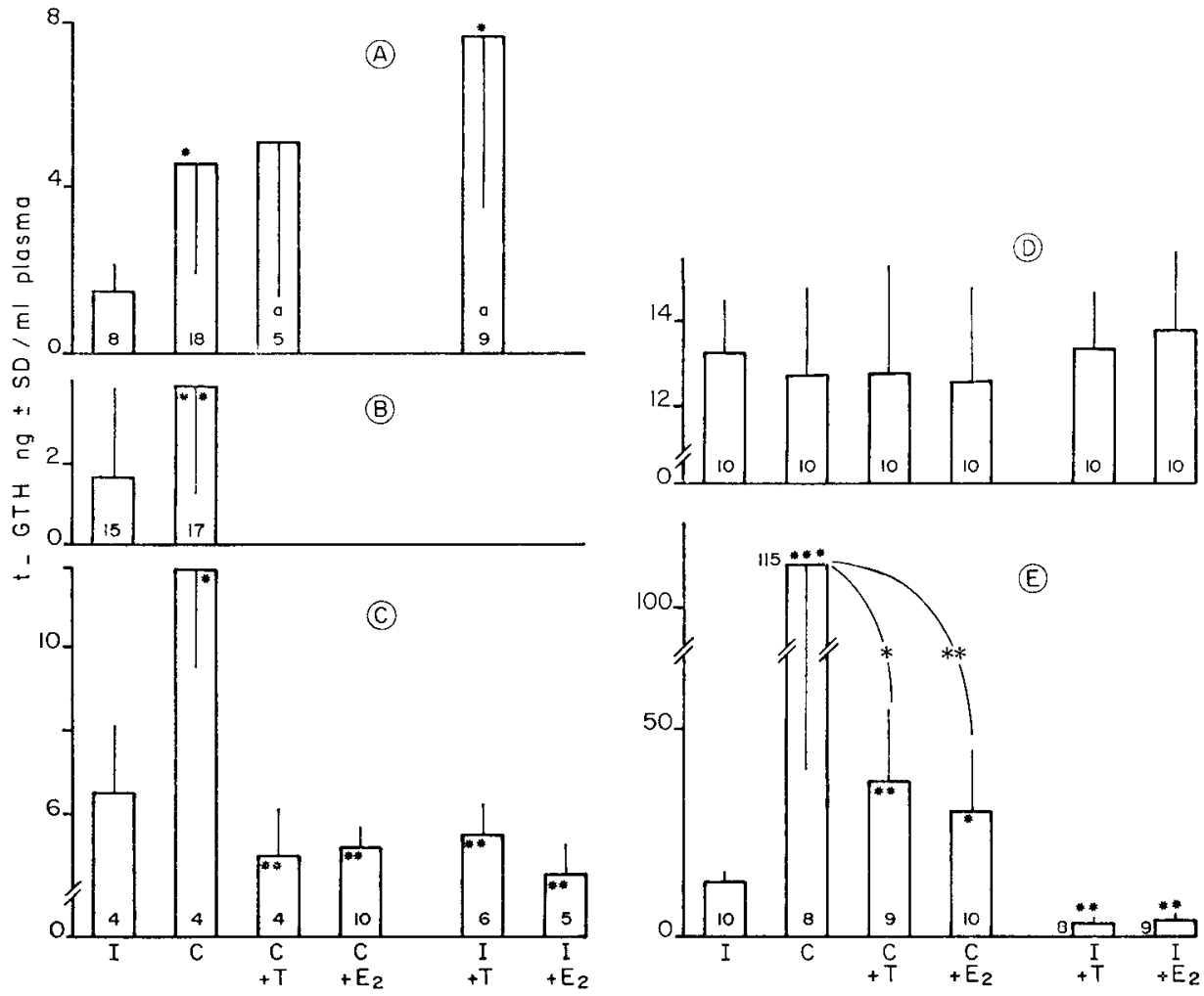

FIG. 1. - Changes in immunoreactive t-GTH after castration and replacement therapy of $T$ and $E_{2}$ in castrates (C) and infacts (I).

A : Day of castration (Cast.) $29 / 3$; day of blood sampling (S) $13 / 4$; B : Cast. : $12 / 4$; S : 31/5; C : Cast. : $18 / 6$; $S: 28 / 7$; D : Cast. : $14 / 10$; $: 30 / 10$; E : Cast. : $3 / 12$; $S: 6 / 12$.

Numbers correspond to the number of fish sampled at the end of the experiment; $a=T$ replacement therapy carried out with silastic capsule. $\dagger$ test $=*: \mathrm{P}<0.05 ; * *: \mathrm{P}<0.005 ; * * *$ : $\mathrm{P}<0.001$ (comparison with infacts). $*: \mathrm{P}<0.05 ; * *: \mathrm{P}<0.005$; (comparison between castrates and castrates $+\mathrm{T}$ or $\mathrm{E}_{2}$ ). 
Steroid supplementation in castrated and intact males. - Castration was performed at several stages of the reproductive cycle and blood was sampled for GTH measurements several days or weeks later at the time of expected maximum response in the castrates (see fig. 1 for time of castration and duration of the experiments). Steroid supplementation was started on the day of castration in intact or castrated animals and consisted of infraperitoneal administration of testosterone $(\mathrm{T})$ or estradiol $17 \beta$ $\left(E_{2}\right)$ (Roussel). For injection the steroids were first dissolved in $90^{\circ}$ ethanol $(5 \mathrm{mg} / \mathrm{ml})$ and diluted 5 times with saline before injection. Fish weighing between 150 to $250 \mathrm{~g}$ received one injection ( $2.5 \mu \mathrm{g} / \mathrm{g}$ body weight) per week. Controls, intact and castrate fish received only saline +20 p. 100 ethanol. In March testosterone was supplied through silastic capsules inserted in the body cavity (tube was $1.6 \mathrm{~mm}$ external diameter, $0.6 \mathrm{~mm}$ wall thickness, $3 \mathrm{~cm}$ long and after a week released experimentally $13.6 \mathrm{\mu g} / 24 \mathrm{~h} / \mathrm{cm}$ in water at $20^{\circ} \mathrm{C}$ ).

Implantation of $11 \mathrm{KT}$ in the pituitary and supplementation with testicular extracts. In December, when response to castration is maximal, implants of $11 \mathrm{KT}$ (lkapharm) were placed stereotaxically in the pituitary of castrates (Billard and Peter, unpublished) and pellets for implantation were prepared according to Billard and Peter (1977). After castration in December, testes were stored in liquid nitrogen and then homogenized. Two extractions of the testes were carried out; one lead to a cytosol after $90 \mathrm{~mm}$ centrifugation at $105000 \mathrm{~g}$ (extract no 1) and the other corresponded to a steroid-free pellet after alcoholic precipitation (extract no 2 ). A control extract was made from liver in a similar manner as for extract $n^{\circ} 2$. Before injection the protein concentration was adjusted to $12.75 \mathrm{mg} / \mathrm{ml}$ (Folin) in all extracts. On the day of castration, a castrate control group $(n=8)$ received blank implantation in the pituitary and a castrate experimental group received $11 \mathrm{KT}$ implants. Three other castrate groups received IP injection of testicular and control extracts on days 3, 5, 7 and 11 post castration $(1 \mathrm{ml} / \mathrm{male} /$ injection). Blood was sampled the same days and at the end of the experiment (day 15). GTH was measured by RIA according to Breton and Billard (1977).

\section{Results.}

Effects of bilateral castration and steroid replacement therapy. - Castration carried out at the end of March when males have reached the end of the period of spermiation and spermatogenesis is at the resting stage, induces a significant rise $(P<0.025)$ of the circulating t-GTH (fig. 1 A). After replacement therapy by an intraperitoneal implant (silastic capsule) of T, plasma t-GTH was not significantly changed in castrates but it was significantly increased in intact fish.

A similar rise of plasma t-GTH $(P<0.025)$ was observed 49 days after castration carried out on April 12 (fig. $1 \mathrm{~B}$ ). When castration is performed in mid-June, a rise of $t-G T H$ is also observed at the end of July $(P<0.05)$ (fig. $1 C)$. At the same time replacement therapy by IP injection of $T$ and $E_{2}$ induced a significant decrease of $t-G T H$ $(\mathrm{P}<0.005)$ in both intacts or castrates as compared to intact controls (fig. $1 \mathrm{C})$. In October, towards the end of spermatogenesis and before spermiation, no change was observed in the t-GTH level after castration or steroid replacement therapy 
(fig. $1 \mathrm{D}$ ). On the contrary in December when males are at the running stage (full spermiation), the t-GTH response to castration is highly significant $(\mathrm{P}<0.005)$ (fig. $1 \mathrm{E})$ Replacement therapy with both $T$ and $E_{2}$ partly reduced this response $(P<0.025$ for $T$ and $P<0.01$ for $E_{2}$ ), but $t-G T H$ level stayed significantly higher than in the intact males $(P<0.05)$. t-GTH level was also reduced $(P<0.005)$ after replacement therapy with $T$ and $E_{2}$ in intact males.

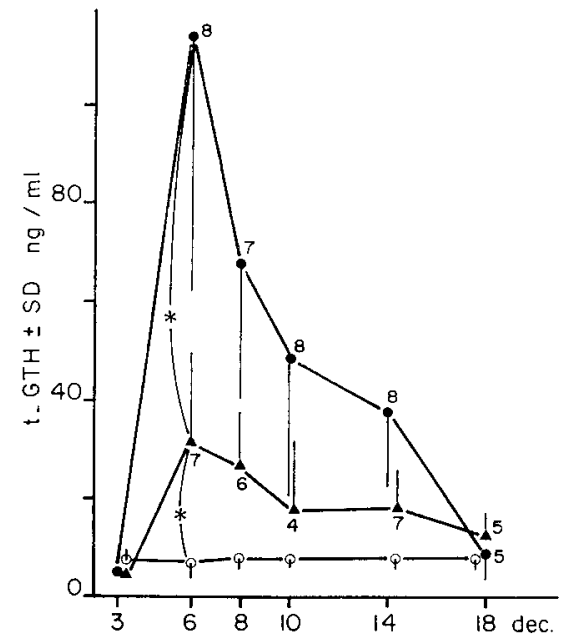

FIG. 2. - Changes in immunoreactive t-GTH after castration and $11 \mathrm{KT}$ implantation in the pituitary of male trout. Day of castration and implantation : 3/12.

$\triangle$ : castrated + $11 \mathrm{KT} ; \circ$ : intact males ; $:$ : castrated ; * : $\mathrm{P}<0.05$.

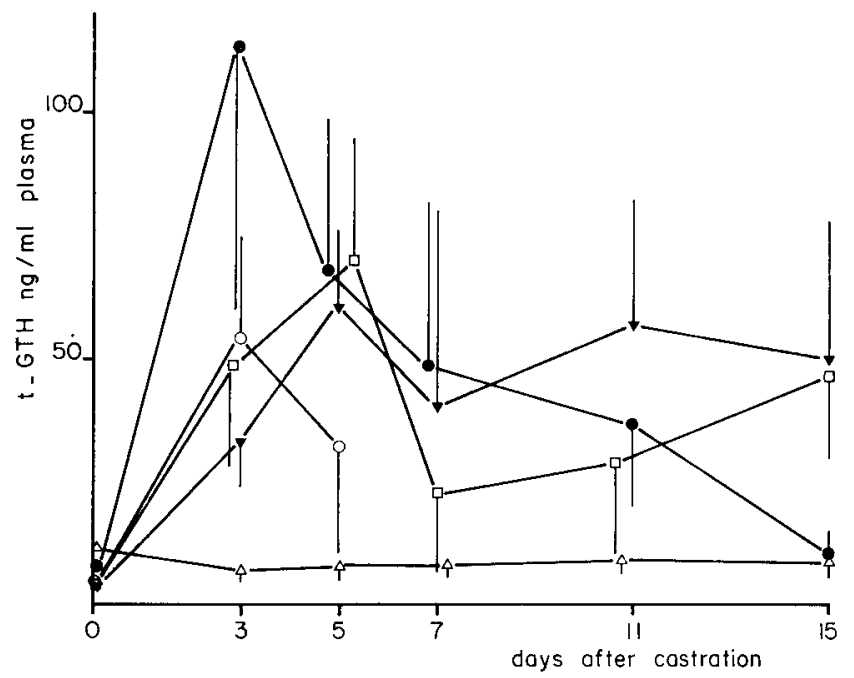

FIG. 3. - Changes in immunoreactive t-GTH affer costration and replacement therapy with testicular extracts (TE).

- : castrated ; a : castrated $+T^{0} n^{0} 1$; o : castrated + TE $n^{0} 2$;

$\checkmark:$ castrated + liver extract (control) $: \Delta:$ intact male.

Day of castration : $3 / 12$. Volume $: 1 \mathrm{ml} /$ injection. 
Effects of implantation of $11 \mathrm{KT}$ in the pituitary and injection of testicular extracts in castrates in December. - The high and short 1-GTH rise which follows castration was significantly reduced by intrapituitary implants of $11 \mathrm{KT}$ although it remained significantly higher than in the intact controls (fig. 2). Injection of testicular extracts slightly prevented the post-castration rise of t-GTH (fig. 3) but values are not significantly different. In addition liver extract had the same effect as TE no 1.

\section{Discussion.}

Castration at most stages of the spermatogenetic cycle induced a significant rise of immunoreactive t-GTH as previously observed (Billard ef al., 1977) : in March and April (sexual rest), July (beginning of spermatogenesis) and December (full spermiation), but not in October when spermatogenesis is almost completed or before the onsef of spermiation. In this case, the post-castration GTH rise may have occurred earlier than when blood samples were taken for GTH measurements.

The response to replacement therapy in castrates and supplementation in intact males also varied according to the stage of the spermatogenetic cycle. In March, T-increased plasma t-GTH in intacts, suggests a positive feed back action on the hypothalamo-pituitary axis. However, it should be pointed out that $T$ was administered via silastic capsules releasing lower doses of $T$ as compared to the injected males. These low doses may be responsible for the positive feed back as shown in rat (Bloch et al., 1974). $T$ and $E_{2}$ therapy was efficient in July and December but had no effect in October, suggesting a change in the gonadal control over the pituitary at this stage. In December, $11 \mathrm{KT}$ is also shown to be involved in the negative feed back (fig. 2). However, T, $E_{2}$ and $11 \mathrm{KT}$ independently did not completely prevent the rise of GTH ; they may act when they are present together. Other factors may also be responsible for the negative feed back. If does not seem that those factors were present in the testicular extract since the castration rise was not significantly prevented by the extracts. Clarification of the active substances requires further experimentation using more purified material.

Symposium sur la Reproduction des Poissons Paimpont, France, 19-21 septembre 1977.

Acknowledgments. - This work was supported by a grant from NATO (No 1035). We are very grateful to Mrs. Gill Campbell, Drs. R. E. Peter and L. Crim for help and fruitful discussions.

Résumé. L'existence d'une rétroaction testiculaire sur l'axe hypothalamo-hypophysaire a été étudiée chez la truite Arc-en-ciel après castration bilatérale et supplémentation par des stéroïdes et des extraits testiculaires. Les expériences ont été conduites à diverses périodes du cycle spermatogénétique : mars-avril (repos sexuel), juin (initiation de la spermatogenèse), octobre (fin de la spermatogenèse et avant spermiation), et en décembre (spermiation). La réponse au traitement est appréciée par les niveaux de t-GTH immunoréactive dans le plasma.

En mars-avril, le niveau de t-GTH plasmatique qui est faible $(<2 \mathrm{ng} / \mathrm{ml})$ chez les mâles intacts se trouve multiplié par trois après castration $(P<0.05)$. Des implants intra- 
abdominaux de testostérone en tube de silastique ne changent pas les niveaux de t-GTH des castrés, mais provoquent une augmentation significative $(P<0.05)$ chez les mâles intacts. En juin la castration est suivie d'une augmentation significative de t-GTH. Cette augmentation est supprimée après injection de testostérone $(T)$ et estradiol $\left(E_{2}\right)$. Chez les mâles intacts l'administration de $T$ et $E_{2}$ provoque une baisse significative de t-GTH. En octobre, $\mathrm{t}-\mathrm{GTH}$ atteint $13 \mathrm{ng} / \mathrm{ml}$ de plasma et n'est pas modifiée après castration et après traifement avec $T$ et $E_{2}$ chez les castrés et les intacts. En décembre, les niveaux de t-GTH sont multipliés par 7 après castration. Cette augmentation est au moins partiellement diminuée par injection de $T$ ef $E_{2}$ et par implantation stéréotaxique de $11 \mathrm{KT}$ dans l'hypophyse. Elle n'est pas significativement modifiée après injection d'extraits testiculaires. A cette période, les stéroïdes apparaissent être le facteur principal impliqué dans le feed back exercé par le testicule au niveau hypothalamo-hypophysaire.

\section{References}

BILLARD R., RICHARD M., BRETON B., 1977. Stimulation of gonadotropin secretion after castration in rainbow trout. Gen. comp. Endocr., 33, 163-165.

BILLARD R., PETER R. E., 1977. Gonadotropin release after implantation of anti-estrogens in the pituitary and hypothalamus of goldfish, Carossius auratus. Gen. comp. Endocr., 32, 213-220.

BLOCH G. J., MASKEN K., KRAGT C. L., GANONG N. F., 1974. Effect of testosterone on plasma $\mathrm{LH}$ in male rat of various ages. Endocrinology, 94, 947-951.

BRETON B., BILLARD R., 1977. Effects of photoperiod and temperature on plasma gonadotropin and spermatogenesis in the rainbow trout (Salmo gairdneri Richardson). Ann. Biol. anim. Bioch. Biophys., 17, 331-340.

IDLER D. R., HORNE E. A., SANGALANG G. B., 1971. Identification and quantification of the major androgens in testicular and peripheral plasma of Atlantic salmon (Solmo salar) during sexual maturation. Gen. comp. Endocr., 16, 257-267. 